\title{
The idea of tomography was published together with the news of the discovery of Röntgen rays-a historical note
}

\author{
Robert F. Dondelinger ${ }^{1}$
}

Received: 28 January 2020 / Accepted: 4 February 2020 / Published online: 26 February 2020

(C) European Society of Radiology 2020

The news of the discovery of Röntgen rays was made known to the world on January 5, 1896 [1].

Having observed the evidence of an unidentified type of radiation for the first time on November 8, 1895, Wilhelm Conrad Röntgen (1845-1923) reported it during an interview given in early 1896 [2]. The professor of physics at the University of Würzburg made this serendipitous discovery at his personal research laboratory. Röntgen conducted intense experiments with the unknown type of rays during the months of November and December without a witness. He obtained a radiograph of the left hand of his wife Anna Bertha (18391919) on Sunday, December 22, 1895 [3]. Röntgen drafted a manuscript, entitled "On a new kind of rays. Preliminary communication," describing their physical properties. He submitted the results of his research, which contained neither formula nor illustration, to the journal of the Physical Medical Society of Würzburg, on Saturday, December 28, 1895. The article was accepted without request for revision. Remarkably, no oral presentation was required before publication. Röntgen's contribution was inserted in the last edition of 1895, immediately before going to print [4]. The issue was available to subscribers in the first days of January 1896. Röntgen confirmed later that on January 1, 1896, he had sent off-prints together with several photographs obtained with the new rays, to a large number of physicists or allied scientists in Germany and abroad [5]. Franz S. Exner (1849-1926), professor of Physics and head of the Institute of Chemistry and Physics at the University of Vienna, was among the recipients. Röntgen and Exner were familiar with each other since their common apprenticeship under the direction of professor August Kundt (1839-1894) at the polytechnical school of Zurich, around 1868. Exner had convened a meeting of

Robert F. Dondelinger

rdondelinger@chu.ulg.ac.be

1 Department of Medical Imaging, University Hospital Sart Tilman, Domaine Universitaire du Sart Tilman, B35, 4000 Liège, Belgium colleagues on Saturday, January 4, 1896. The professor displayed the photographs and the accompanying scientific article sent out by Röntgen. Ernst Lecher (1856-1926), recently appointed professor of Physics at the German University of Prague, was in the audience. After the meeting, Lecher borrowed from Exner Röntgen's off-print and some of the photographs as a proof of the discovery. On the same evening, he informed his father, Zacharias L. Lecher (18291905), a reporter at the Viennese daily newspaper "Die Presse." The next day, in Sunday edition, on January 5, 1896, an unsigned article was published on the front page, entitled "A sensational discovery" [1]. The name of Röntgen was misspelled "Routgen," either due to the illegible handwriting of Lecher or to the quick typesetting during the night. The article continued on the second page on two columns.

The last paragraph starts as follows, in English translation:

"And if one lets phantasy run free, one can envision that it will become possible to improve the method of photographic process using the rays emitted by a Crookes' tube in such a way, that only a part of the soft tissues of the human body remains transparent, but a deeper layer can be fixed on the plate and thus an inestimable aid would be gained for the diagnosis of numerous other groups of diseases than those of the bones. Such an achievement, such a progress on the opened track would not be out of reach of the possible, provided the preceeding premise will prove correct. We admit that all this is over-audacious phantasy of the future..."

This forecast was nothing less than the suggestion of tomography concomitantly with the announcement of the birth of radiography.

It will remain unknown who formulated the idea of imaging selected slices within a volume by means of X-rays. It is most plausible that the intuition arose from one of the physicists who had discussed Röntgen's discovery the day before around professor Exner. 
The news published by "Die Presse" was echoed by many leading newspapers, gazettes, or scientific journals throughout the world, during the first month of 1896 , starting as soon as January 6 . The original press article contributed more rapidly and efficiently to the spread of X-rays than Röntgen's scientific paper. To the best of my knowledge, no other newspaper elaborated on the futuristic idea of obtaining radiographic tomograms. Thomas A. Edison alluded to it during an interview on January 12. [6]

Conventional radiographic stratigraphy, planigraphy, or tomography came to reality indeed, between 1921 and 1936. Due to a lack of communication, many researchers claimed independently having made a significant contribution to the development of the technical principles [8-11]. The initiators of the tomographic techniques strove to obtain patents of invention rather than publish scientific papers. Neither the early pioneers nor later publications dealing with radiographic tomography made reference to the prediction published by "Die Presse" in 1896.

Despite the fact that this article is the first landmark in the history of X-rays and abundantly quoted in the literature, the prophecy of tomography being printed in the last paragraph on the second page of the newspaper was simply neglected. I found only one mention of my topic in the radiological literature. [12]

Funding The author states that this article has not received any funding.

\section{Compliance with ethical standards}

Guarantor The scientific guarantor of this publication is the author.

Conflict of interest The authors of this manuscript declare no relationships with any companies whose products or services may be related to the subject matter of the article.

Statistics and biometry Not applicable

Informed consent Not applicable

Ethical approval Not applicable
Study subjects or cohorts overlap Not applicable

Methodology

- Personal bibliographic research

\section{References}

1. Eine sensationelle Entdeckung (1896) Die Presse, Wien, $N^{\circ} 5,5$ Jänner : $1-2$

2. Dam HJW (1896) The new marvel in photography. McClure's Magazine New-York 6:403-415

3. Dated notice attached to a radiograph of the hand of Bertha Röntgen. German museum, Munich, Germany

4. Röntgen WC (1896) Über eine neue Art von Strahlen. Vorläufige Mitteilung. Sitzungsberichte der physikalisch-medicinischen Gesellschaft, Würzburg 137:132-141

5. Zehnder L (1935) Röntgens Briefe an Zehnder. Rascher \& Cie. A.G. Zürich Leipzig Stuttgart

6. He takes pictures through the live flesh (1896) The Journal, New York

7. Bocage A-E M (1922) Procédé et dispositifs de radiographie sur plaque en mouvement. République française. Brevet d'invention $\mathrm{N}^{\circ}$ 536.464. Délivré le 13 février 1922

8. Portes FM Chausse M (1922) Procédé pour la mise au point radiologique sur un plan sécant d'un solide ainsi que pour la concentration sur une zone déterminée d'une action radiothérapeutique maximum, et dispostifis enpermettant la réalisation. République française. Brevet d'invention N 541.914. Délivré le 9 mai 1922

9. Pohl E (1927) Verfahren und Vorrichtung zur röntgenphotographischen Wiedergabe eines Körperschnittes unter Ausschluss von davor und dahinter liegenden Teilen. Deutsches Reich. Patentschrift Nr.544200. Patentiert vom 30.November $1927 \mathrm{ab}$

10. Vallebona A (1930) Una modalità di tecnica per la dissociazione radiografica delle ombre applicata allo studio del cranio. Radiol Med 17:1090-1097

11. Ziedses des Plantes BB (1931) Een bijondere methode voor het maken van Röntgenphoto's van schedel en wervelkolom. Ned Tijdschr Geneesk 75:5218-5222

12. Kraft E, Finby N (1981) Beginning of Radiology in 1896. First newspaper report of discovery of X-ray. N Y State J Med 81:805806

Publisher's note Springer Nature remains neutral with regard to jurisdictional claims in published maps and institutional affiliations. 